\title{
Climate, vegetation and fire history during the past 18,000 years, recorded in high altitude lacustrine sediments on the Sanetti Plateau, Bale Mountains (Ethiopia)
}

Betelhem Mekonnen ${ }^{1,2^{*}} \mathbb{D}$, Bruno Glaser ${ }^{1}$, Roland Zech ${ }^{3}$, Michael Zech ${ }^{1,4}$, Frank Schlütz ${ }^{5,6}$, Robert Bussert ${ }^{7}$, Agerie Addis ${ }^{8}$, Graciela Gil-Romera ${ }^{9}$, Sileshi Nemomissa ${ }^{10}$, Tamrat Bekele ${ }^{10}$, Lucas Bittner ${ }^{1,4}$, Dawit Solomon ${ }^{11}$, Andreas Manhart ${ }^{12}$ and Wolfgang Zech ${ }^{12}$

\begin{abstract}
Low-altitude lakes in eastern Africa have long been investigated and have provided valuable information about the Late Quaternary paleohydrological evolution, such as the African Humid Period. However, records often suffer from poor age control, resolution, and/or ambiguous proxy interpretation, and only little focus has been put on highaltitude regions despite their sensitivity to global, regional, and local climate change phenomena. Here we report on Last Glacial environmental fluctuations at about 4000 m asl on the Sanetti Plateau in the Bale Mountains (SE Ethiopia), based on biogeochemical and palynological analyses of laminated lacustrine sediments. After deglaciation at about 18 cal kyr BP, a steppe-like herb-rich grassland with maximum Chenopodiaceae/Amaranthaceae and Plantago existed. Between 16.6 and 15.7 cal kyr BP, conditions were dry with a desiccation layer at 16.3 cal kyr BP, documenting a temporary phase of maximum aridity on the plateau. While that local event lasted for only a few decades, concentrations of various elements (e.g. $\mathrm{Zr}, \mathrm{HF}, \mathrm{Nb}, \mathrm{Nd}$, and $\mathrm{Na}$ ) started to increase and reached a maximum at 15.8-15.7 cal kyr BP. We interpret those elements to reflect allochthonous, aeolian dust input via dry northerly winds and increasingly arid conditions in the lowlands. We suggest an abrupt versus delayed response at high and low altitudes, respectively, in response to Northern Hemispheric cooling events (the Heinrich Event 1). The delayed response at low altitudes might be caused by slow negative vegetation and monsoon feedbacks that make the ecosystem somewhat resilient. At $\sim 15.7$ cal kyr BP, our record shows an abrupt onset of the African Humid Period, almost 1000 years before the onset of the Bølling-Allerød warming in the North-Atlantic region, and about 300 years earlier than in the Lake Tana region. Erica pollen increased significantly between 14.4 and 13.6 cal kyr BP in agreement with periodically wet and regionally warm conditions. Similarly, intense fire events, documented by increased black carbon, correlate with wet and warm environmental conditions that promote the growth of Erica shrubs. This allows to conclude that biomass and thus fuel availability is one important factor controlling fire events in the Bale Mountains.
\end{abstract}

Keywords: Bale Mountains, High-altitude lacustrine sediments, Heinrich event 1, African humid period, Fire, Erica

\footnotetext{
*Correspondence: betymekonnen19@gmail.com

${ }^{1}$ Institute of Agricultural and Nutritional Sciences, Soil Biogeochemistry,

Martin Luther University Halle-Wittenberg, Halle, Germany

Full list of author information is available at the end of the article
}

\section{Introduction}

East African lakes have attracted scientific interest for decades. This is because global atmospheric circulation systems strongly influence this region and its hydrological dynamics (e.g. Thompson et al. 2002; Costa et al. 2014; Lamb et al. 2018). For instance, during the Last 
Glacial Maximum (LGM; 23-18 kyr BP) the decrease of tropical sea surface temperatures resulted in glaciation on East African Mountains (Mount Kenya, Kilimanjaro, Ruwenzori, and Ethiopian highlands) (Osmaston et al. 2005; Mark and Osmaston 2008). In addition, the southward shift of the Intertropical convergence zone (ITCZ) during ice rafting episodes throughout Heinrich event 1 (H1) are considered as a major cause for the dry event in northern and southeastern Africa around 16-17 cal kyr BP (Tierney et al. 2008; Marshall et al. 2007; Stager et al. 2011; Mohtadi et al. 2014). During the African humid period (AHP) maximum northern Hemisphere summer insolation shifted the rain belt associated with the ITCZ to the north (Bastian et al. 2021), generating increased rainfall across Northern Africa which turned the Saharan desert into green savanna (Gasse 2000). Palaeoclimatic studies suggest the southward extension of the AHP to eastern Africa (Tierney et al. 2008; Tierney and DeMenocal 2013; Costa et al. 2014).

Besides, lacustrine sediments (Tiercelin et al. 2008; Bittner et al. 2020; and many others), tropical glaciers (Gasse 2000; Thompson et al. 2002), peat bogs (Bonnefille and Mohammed 1994; Brown et al. 2007) and marine sediments (Camuera et al. 2021; Tierney and deMenocal 2013) have been serving as potential archives for the reconstruction of paleoenvironmental fluctuations in eastern Africa. However, the regional, topographic, and climate complexities, together with dating inaccuracy and lack of unambiguous proxies, lead to differences in the reconstructed timing of the onset and termination of major climatic events such as H1 and AHP across sites (Lamb et al. 2007; Tierney et al. 2011; Costa et al. 2014; Bastian et al. 2021). Moreover, the impact of these drastic climatic events on the migration of humans and on vegetation dynamics is yet not fully understood.

The highlands of the Bale Mountains in southeastern Ethiopia are promising sites for studying paleoenvironmental fluctuations. Their unique exposition to main atmospheric circulation systems (SW monsoon, SE monsoon, NE trades, and NW disturbances) (Miehe and Miehe 1994; Hillman 1986; Camberlin 2018) contribute to their climate sensitivity. In addition, the special geomorphological features, characterized by high altitudes up to $4377 \mathrm{~m}$ above sea level (asl), by moraines and small glacial depressions, support the reconstruction of the landscape evolution (Nicholson 2000). During MIS 3, the Bale Mountains were one of the most extensively glaciated mountains in Ethiopia (Messerli 1980; Osmaston et al. 2005; Groos et al. 2021). Groos et al. (2021) suggest that about $265 \mathrm{~km}^{2}$ of the Bale Mountains were icecovered between 42 to $28 \mathrm{kyr} \mathrm{BP}$, well before the onset of the global LGM. This caused a temperature decrease and a downward shift of Afroalpine vegetation. Umer et al. (2007) and Ossendorf et al. (2019) suggested that the glaciers retreated from the Bale Mountains at 15.916.7 cal kyr BP. Geochemical and pollen results from Lake Garba Guracha, in a north-exposed, deeply incised trough valley at $3950 \mathrm{~m}$ asl, and from peat deposits on the Sanetti Plateau, inform about Late PleistoceneHolocene climate fluctuations (Tiercelin et al. 2008; Bittner et al. 2020) and respective vegetation changes (Umer et al. 2007; Kuzmicheva et al. 2013, 2014; GilRomera et al. 2019). These studies suggest that the warm and humid conditions during the early Holocene led to the expansion of Erica vegetation on the Sanetti Plateau, and dry climate and natural and/or human-induced fires might be major causes for the current patches of Erica on the Plateau. A study by Ossendorf et al., (2019), revealed human settlements in high elevation $(3469 \mathrm{~m}$ asl) already during 47-31 cal kyr BP. Gil-Romera et al. (2019) reported that fire played a major role in determining the ecological dynamics of the Erica vegetation on the Bale Mountains. However, the influence of humans on the vegetation remains unclear. Open questions are: (1) Did the high altitudes of the Sanetti Plateau experience similar climatic fluctuations in intensity and timing as the lower regions in northern and eastern Africa during the Late Glacial? (2) Did the highlands of the Sanetti Plateau deglaciate at the same time as the north exposed trough valleys? (3) When and to what degree did Erica occupy the high altitudes of the Sanetti Plateau, where at present only patches can be found? (4) Are these patches of Erica relics documenting climate deterioration or human-induced fire?

In order to address these questions, and to better understand the paleoecological evolution of these high altitudes above the upper timberline, we analysed laminated lake sediments in high resolution, deposited in a glacial depression on the Plateau in about $4000 \mathrm{~m}$ asl using a multi-proxy approach. The depression has no noteworthy outflow and its catchment is not densely vegetated, thus being highly sensitive to local and regional environmental fluctuations.

\section{Site information and methods/experimental}

\subsection{Study area}

The Bale Mountains covering an area of $2200 \mathrm{~km}^{2}$ include the Sanetti Plateau, which is the largest alpine ecosystem in Africa (Fig. 1). The area is widely perceived as natural (Miehe and Miehe 1994; Kidane et al. 2012). The Plateau (Fig. 1) extends between ca. 3800 to $4100 \mathrm{~m}$ asl, surrounded by the peaks of Tullu Konteh (4050 m asl) and Tullu Dimtu (4377 $\mathrm{m}$ asl), the second-highest peak of the country (Hillman 1988; Messerli and Winiger 1992). Erratic boulders, moraines, small lakes present on the plateau and in trough valleys are clear indicators 




of former glaciations (Osmaston et al. 2005). The parent rocks comprise Oligo-Miocene basalts and Quaternary rhyolites with trachytes, which weather to brown or brownish-black silty loams (Billi 2015). Muddy Gleysols are developed in depressions (Yimer et al. 2006).

Due to the annual migration of the ITCZ between $10^{\circ}$ North and South, the climate of the Bale Mountains is characterized by a pronounced rainfall seasonality with a short dry (November to February) and a long rainy season (March to October) (Levin et al. 2009; Costa et al. 2014). The rainfall pattern is bimodal, with a peak from July to October, followed by a second peak from March to June (Kidane et al. 2012). The rain-bearing air masses derive from the Indian Ocean and the Atlantic Ocean via the Congo Basin (Gasse 2000; Tierney et al. 2011; Costa et al. 2014; Lemma et al. 2020), whereas northerly winds dominate during the dry season. In Dinsho (3170 $\mathrm{m}$ asl), the mean maximum temperature is $11.8^{\circ} \mathrm{C}$ while the mean minimum temperature ranges from 0.6 to $10{ }^{\circ} \mathrm{C}$, with frequent frost occurring in the high mountain areas during winter season (November to January) (Hillman 1986; Tiercelin et al. 2008). The highest precipitation and humidity occurs in the southern part of the mountains with $1000-1500 \mathrm{~mm} / \mathrm{a}$, while the northern part exhibits annual rainfall ranging between 800 and $1000 \mathrm{~mm} / \mathrm{a}$ (Miehe and Miehe 1994; Umer et al. 2007).

The south to north rainfall gradient and the altitudinal temperature gradient stratify the vegetation into the Afromontane forest, the Ericaceous belt, and Afroalpine zone (Hedberg 1951; Friis 1986). The Afromontane forest spans from $\sim 1450$ to $3200 \mathrm{~m}$ asl in southern exposition, and from $\sim 2800$ to $3300 \mathrm{~m}$ asl along northern slopes. The southern declivity comprises Podocarpus gracilior associated with Syzygium guineense and Aningeria adolfi-friederici, whereas the northern slopes are mainly dominated by Juniperus procera, Hagenia abyssinica, and Hypericum revolutum (Friis 1986; Bussmann 1997). The Ericaceous belt covers $\sim 90,000$ ha between ca. 3200 and $3800 \mathrm{~m}$ asl and is dominated by Erica arborea L. and Erica trimera (Engl.) (Hailemariam et al. 2016). While the lower boundary of the Ericaceous belt (3300-3500 m asl) is covered with Erica-dominated Hagenia-Hypericum forests, the central part comprises monotonous Erica trimera stands, which continues to the upper limit (ca. $3800 \mathrm{~m}$ asl) of the boundary. The Afroalpine vegetation above $3800 \mathrm{~m}$ asl is open and rich in Tussock grasses and mainly dominated by Helichrysum splendidumAlchemilla haumannii dwarf-scrubs and Giant Lobelia (L. rhynchopetalum) (Yineger et al. 2008), accompanied by patches of Erica, growing between big boulders along steep slopes (Miehe and Miehe 1994).

\subsection{Sampling}

We investigated a depression, located in an extended plain on the Sanetti Plateau, above the upper limit of the Erica belt at $3970 \mathrm{~m}$ asl (Fig. $1 ; 6^{\circ} 53.3433^{\prime} \mathrm{S}$ and $\left.39^{\circ} 54.5217^{\prime} \mathrm{E}\right)$. A pit was dug down to the glacial boulders in a depth of $255 \mathrm{~cm}$ to prepare a profile named "B4" (Fig. 2). Subsequently, sediments were described (color, texture, structure, ect.) and sampled every $2 \mathrm{~cm}$ from 55 to $255 \mathrm{~cm}$, representing humic-rich lacustrine, partly laminated material, and every 5 to $10 \mathrm{~cm}$ from the brownish upper part, rich in reddish mottles. Samples were air-dried and stored in plastic bags. In addition, 10 sediment samples were collected from the pit for radiocarbon dating. The air-dried samples were analyzed for elemental and mineral compositions, electrical conductivity (EC), $\mathrm{pH}\left(\mathrm{H}_{2} \mathrm{O}\right)$, stable $\mathrm{C}$ isotopes, alkanes, pollen, 
(A)





\section{$\mathbf{0}$}



clayey sandy silt,

light brown, with

$\sim \sim$

$\sim \sim \sim$

gleyic proper es desiccation surface

$\sim \sim \sim$

$71-$



grey clayey silt, partly laminated

10.2

13.6

ता $\pi$ तn $\pi$ plant remains, swamp

15.2

grey clayey silt, partly laminated

15.7



(B)

unit 3

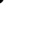


Table 1 Radiocarbon ages using Accelerated Mass Spectrometry of alkali soluble organic matter; calibrated according to Blaauw and Christen (2011)

\begin{tabular}{|c|c|c|c|c|c|}
\hline Lab number & $\begin{array}{l}\text { Sample depth } \\
\text { (cm) }\end{array}$ & Dated material & $\begin{array}{l}{ }^{14} \mathrm{C} \text { age (uncalibrated } \\
\text { a BP) }\end{array}$ & $\begin{array}{l}\text { Cal. (INTCAL13, } 2 \text { Sigma } \\
\text { ranges) }\end{array}$ & $\begin{array}{l}{ }^{14} \mathrm{C} \text { age (calibrated, } \\
\text { median cal year BP) }\end{array}$ \\
\hline Erl-5563 & 27 & Bulk sediment & $4650 \pm 55$ & $5078-5532$ & 5396 \\
\hline Erl-5564 & 40 & Bulk sediment & $7718 \pm 72$ & $8225-8678$ & 8481 \\
\hline Erl-5173 & 63 & Bulk sediment & $9047 \pm 108$ & $9603-10,472$ & 10,052 \\
\hline Erl-5092 & 72 & Bulk sediment & $11,856 \pm 86$ & $13,436-13,969$ & 13,667 \\
\hline Erl-5175 & 101 & Bulk sediment & $12,696 \pm 96$ & $14,372-15,241$ & 14,876 \\
\hline Erl-5173 & 123 & Bulk sediment & $13,214 \pm 95$ & $15,155-15,867$ & 15,518 \\
\hline Erl-5093 & 160 & Bulk sediment & $13,525 \pm 106$ & $15,979-16,568$ & 16,276 \\
\hline Erl-5172 & 207 & Bulk sediment & $14,094 \pm 119$ & $16,916-17,458$ & 17,193 \\
\hline Erl-5565 & 233 & Bulk sediment & $14,485 \pm 81$ & $17,472-17,958$ & 17,701 \\
\hline Erl-5568 & 255 & Bulk sediment & $14,681 \pm 92$ & $17,879-18,653$ & 18,173 \\
\hline
\end{tabular}

$$
\mathrm{CPA}=\left[\frac{\mathrm{Al}_{2} \mathrm{O}_{3}}{\mathrm{Al}_{2} \mathrm{O}_{3}+\mathrm{Na}_{2} \mathrm{O}}\right] \times 100
$$

Qualitative mineral identification was carried out on bulk samples $(n=100)$ using X-ray diffraction. The powdered samples were packed into aluminum sample holders and scanned in a Philips PW 1710 diffractometer from 3 to $80^{\circ} 2^{\theta}$ with $\mathrm{Cu} \mathrm{K} \alpha$ radiation generated at $50 \mathrm{kV}$ and $30 \mathrm{~mA}$, at $0.02^{\circ} 2 \theta$ step size and $2.5 \mathrm{~s}$ step time. Phases identified in the samples are quartz, feldspar, pyroxene (probably mainly augite), clay minerals, hematite, pyrite, gypsum, and amorphous silica. No special clay mineral analysis was performed, yet characteristic peaks of clay minerals between $\sim 6-12.5$ and $\sim 60-62^{\circ} 2^{\theta}$ show a wide range of clay minerals, including smectite, chlorite, illite, kaolinite and mixed-layer minerals.

\subsubsection{Organic geochemistry}

Total organic carbon (TOC) and total nitrogen $(N)$ of homogenized samples $(n=103)$ were quantified by dry combustion on a Vario EL elemental analyser (Elementar, Langenselbold, Germany). In order to complement the organic matter source identification and preservation status, $n$-alkanes and hydrogen index (HI) were analysed in 34 samples (Talbot and Livingstone 1989). $n$-Alkanes were extracted by soxhlet extraction using dichloromethane (DCM) and methanol (1:1) as solvents for $24 \mathrm{~h}$ (Zech and Glaser 2008). After adding $50 \mu \mathrm{l}$ of $5 \alpha$ androstane as an internal standard, the excess solvent was removed by rotary evaporation and transferred to aminopropyl columns. Subsequently, $n$-alkanes were eluted with $3 \mathrm{ml}$ of hexane DCM/MeOH (1:1). Finally, $n$-alkanes were quantified using gas chromatography (SHIMADZU, GC-2010, Kyoto Japan) equipped with an SPB-5 columns of $30 \mathrm{~m}$ length, $0.25 \mathrm{~mm}$ ID, $0.25 \mu \mathrm{m}$ film thickness, and detected using a flame ionization detector (FID). Here, we used the $n$-alkane ratio Paq $\left(\mathrm{C}_{23}+\mathrm{C}_{25}\right) /\left(\mathrm{C}_{23}+\mathrm{C}_{25}+\mathrm{C}_{29}+\right.$ $\mathrm{C}_{31}$ ) to identify the source of organic matter. HI was analysed by pyrolysis of dried $\left(40{ }^{\circ} \mathrm{C}\right)$ and fine powdered bulk sediments (Talbot and Livingstone 1989).

We measured the natural abundance of $\delta^{13} \mathrm{C}(n=101)$ by dry combustion of a $40 \mathrm{mg}$ homogenized aliquot with a Fision 1108 elemental analyser coupled to a Delta S gas isotope ratio mass spectrometer (EL-IRMS) with a Conflow III interface (Thermo Finnigan MAT, Bremen, Germany). Sucrose (ANU, IAEA, Vienna, Austria) and $\mathrm{CaCO}_{3}$ (NBS 19, TS limestone) were used as calibration standards for $\delta^{13} \mathrm{C}$. The precision of $\delta^{13} \mathrm{C}$ measurement was $0.2 \%$. In addition to bulk stable isotopes, we measured compound-specific carbon isotopes $\left(\delta^{13} \mathrm{C}\right)$ of long chain terrestrial $n$-alkanes $\mathrm{C}_{27}, \mathrm{C}_{29}$ and $\mathrm{C}_{31}$ to complement on the paleovegetation reconstruction $(\mathrm{C} 3$ vs C4). Compound-specific $\delta^{13} \mathrm{C}$ analyses of long chain $n$-alkanes $\left(\mathrm{C}_{27}, \mathrm{C}_{29}\right.$ and $\left.\mathrm{C}_{31}\right)$ were carried out and measured as described above.

Black carbon (BC) refers to polycondensed aromatic moieties formed during thermochemical combustion. While charcoal is usually detected visually using a microscope, BC is usually detected through chemical extraction, which enables to quantify the complex signature of pyrogenic carbon more precisely, especially when charcoal is not visible anymore. Thus, $\mathrm{BC}$ allows the reconstruction of fire events even if soot or char are not visible. Moreover, its polycyclic aromatic structure resists chemical and biological degradation in soil (Glaser et al. 1998; Wang and Li 2007; Wiedemeier et al. 2015) and persists for a long period of time in soil and sediments (Kuzyakov et al. 2014). We analysed BC $(n=72)$ using benzene polycarboxylic acids (BPCAs) as molecular markers following Glaser et al. (1998) and modified according to Brodowski et al. (2005). Five hundred mg of each sample was hydrolyzed with $10 \mathrm{ml} 4 \mathrm{M}$ TFA for $4 \mathrm{~h}$ at $105^{\circ} \mathrm{C}$. 
The hydrolyzed samples were filtrated on glass fiber filters and rinsed several times with de-ionized water to remove polyvalent cations. Subsequently, the samples were digested with $65 \%$ nitric acid for $8 \mathrm{~h}$ at $170{ }^{\circ} \mathrm{C}$ in a high-pressure digestion apparatus. The solution was passed through Dowex $50 \mathrm{~W}$ resin columns (200 to 400 meshes) to remove polyvalent cations. After derivatization, BPCAs were separated using GC and detected using FID with an injection temperature of $300{ }^{\circ} \mathrm{C}$.

\subsubsection{Palynomorph analysis}

For palynological analyses, samples of $1 \mathrm{ml}$ were prepared using standard procedures, including Lycopodium spores as exotic markers, acetolysis, HF treatment, and ultrasonic sieving $(5 \mu \mathrm{m})$, and storage in glycerol (Stockmarr 1971). Microscopic analyses took place under $400 \times$ magnifications, backed by oil immersion $(1250 \times)$. For pollen identification, we used an existing reference collection of $\sim 5000$ slides (in Goettingen) and relevant literature (Gosling et al. 2013; Schüler and Hemp 2016). The nomenclature of the common types follows Beug (2004). Detailed analyses were carried out on 38 samples from the lower part of the profile $(251-69 \mathrm{~cm})$ with pollen counting sums of about 250 to 300 per sample. Pollen influx (grains cm $\mathrm{cm}^{-1} \mathrm{a}^{-1}$ ) was calculated using exotic Lycopodium spore markers. To estimate humidity conditions, we calculated the A/C (Artemisia/Chenopodiaceae) ratio (Van Campo and Gasse 1993; Herzschuh 2007; Li et al. 2010) by dividing the number of Artemisia by that of Chenopodiaceae/Amaranthaceae. Poaceae pollen were size differentiated between small $(<37 \mu \mathrm{m})$ and large $(>37 \mu \mathrm{m})$ diameter grains. Counts of the larger grains allow an approximate estimate of $\mathrm{C} 4$ grasses, which produce larger pollen grains than C3 Poaceae (Jan et al. 2015). Diagrams were plotted with the software C2 (Juggins 2007).

\section{Results}

\subsection{Age-depth model and sedimentation rates}

B4 profile records sedimentation during the last $18.2 \mathrm{cal}$ kyr BP. Our age-depth model (Fig. 3) illustrates that the sedimentation rate was 0.05 and $0.01 \mathrm{~cm}$ per year between 18.2 and $13.6 \mathrm{cal} \mathrm{kyr} \mathrm{BP}$ and from $10.5 \mathrm{cal} \mathrm{kyr}$ $\mathrm{BP}$ to present, respectively. Between 13.6 and $10.5 \mathrm{cal} \mathrm{kyr}$ $\mathrm{BP}$, a sedimentation hiatus is indicated.

\subsection{Lithostratigraphy and interpretation of the depositional environment}

The B4 sediments can be stratified into three units (Fig. 2). The lowermost unit 1 from 255 to $175 \mathrm{~cm}$ (18.2$16.6 \mathrm{cal}$ kyr BP) is a dark-grey, laminated, silty clay with low sand content. It was deposited above a thin greyish sandy silt layer and basalt boulders. Unit 2, from 175 to
$71 \mathrm{~cm}$ depth, is a grey, partly laminated silty clay, deposited between 16.6-13.6 cal kyr BP. A stiff sandy-silty light layer, preserved between 167 and $160 \mathrm{~cm}$, likely documents intensive desiccation of the B4 depression at about $16.3 \mathrm{cal}$ kyr BP. From 120 to $110 \mathrm{~cm}(\sim 15.4-15.2 \mathrm{cal}$ kyr BP) plant root relics occur displaying swampy, shallowwater conditions. The upper lithostratigraphic unit 3 is about $70 \mathrm{~cm}$ thick, deposited during the last $10 \mathrm{cal} \mathrm{kyr} \mathrm{BP}$. It comprises light brown, weakly clayey, sandy silt with red mottles and bleached aggregate surfaces, showing water-logging during the rainy season. Unit 3 is strongly influenced by gleysation, which makes paleoenvironmental interpretations and regional comparisons ambiguous. Therefore, in the following, we present geochemical and palynological results only from units 1 and 2 in detail.

\subsection{Grain size and geochemical results}

\subsubsection{Unit 1: 255-175 cm (18.2-16.6 cal kyr BP)}

According to Fig. 4 and Additional file 1, clay and silt contents are high (partly up to $60 \%$ and $40 \%$, respectively) and weakly fluctuating, whereas the sand contents are very low. TOC values, being low at the bottom of the core, constantly increase from $\sim 0.7$ to $\sim 7 \%$ in $239 \mathrm{~cm}$; then high values $(\sim 7 \%)$ persist until the top of unit 1 . Low $\mathrm{TOC} / \mathrm{N}$ values at the bottom of the profile increase to an average value $<12$ (Fig. 4). HI values range between 107 and 266, with low values at the bottom of the profile.

Our results show an average $\delta^{13} \mathrm{C}$ value of $-14.3 \%$ with a slight decrease from the bottom to the top of unit 1. Analyses of water plants (Potamogeton thunbergii, Ranunculus trichophyllus) and algae (Pediastrum), sampled from nearby shallow lakes, resulted in $\delta^{13} \mathrm{C}$ values of $-18.6,-15.5$, and $-17.3 \%$, respectively. Modern terrestrial plants growing around the B4 depression are characterized by $\delta^{13} \mathrm{C}$ values between - 30.1\%o (Helichrysum argyaranthum) and - 26.9\%o (Alchemilla fischeri). Compound-specific analysis of long chain $n$-alkanes $\mathrm{C}_{27}, \mathrm{C}_{29}$, and $\mathrm{C}_{31}$ revealed $\delta^{13} \mathrm{C}$ values of $-27,-25.6$, and $-25.1 \%$, respectively. Paq values increase from 0.27 at $244.5 \mathrm{~cm}$ to 0.44 at $175 \mathrm{~cm}$. Despite high value at the bottom of the profile, $\mathrm{BC}$ values were very low in this unit (around $10 \mathrm{~g} \mathrm{~kg}^{-1}$ TOC) increasing between 195 and $175 \mathrm{~cm}(\sim 16.9-16.6 \mathrm{cal} \mathrm{kyr} \mathrm{BP})$ to around $30 \mathrm{~g} \mathrm{~kg}^{-1}$ TOC.

Lithogenic elements such as $\mathrm{Zr}, \mathrm{Hf}, \mathrm{Nb}$, and $\mathrm{Na}_{2} \mathrm{O}$ show minimum values except for a slight increase at $210 \mathrm{~cm}$ and $\sim 190 \mathrm{~cm}(\sim 17.2$ and 17.0 cal kyr BP) (Fig. 5). Besides primary minerals such as quartz, feldspar, and pyroxene, unit 1 sediments contain traces of pyrite and gypsum. CPA values do not show fluctuation except a slight decrease at 17.2 and $\sim 16.9 \mathrm{cal} \mathrm{kyr} \mathrm{BP}$. 



Fig. 3 Bayesian age-depth model for profile B4 according to Blaauw and Christen (2011). Top left: The log-likelihood of the model fit for the saved iterations of the model, top middle: prior and posterior distribution of accumulation rate, and top right: prior and posterior distribution of the autocorrelation in accumulation rates (memory) and the time gap (hiatus size) at the end. Bottom panel shows the calibrated ${ }^{14} \mathrm{C}$ dates (transparent blue) and the age-depth model (darker greys) indicate more likely calendar ages; grey stippled lines show 95\% confidence intervals; red curve shows single 'best' model based on the mean age for each depth

\subsubsection{Unit 2: 175-71 cm (16.6-13.6 cal kyr BP)}

Unit 2 starts at $175 \mathrm{~cm}$ depth with slightly increasing values of the lithogenic proxies (Fig. 5). Most striking is a pronounced sand maximum and a TOC minimum in $\sim 160 \mathrm{~cm}$, corresponding to $\sim 16.3 \mathrm{cal} \mathrm{kyr} \mathrm{BP} \mathrm{(Fig.} \mathrm{4).}$ Strongly increasing values of the lithogenic compounds such as $\mathrm{Zr}, \mathrm{Na}_{2} \mathrm{O}, \mathrm{K}_{2} \mathrm{O}, \mathrm{Hf}, \mathrm{Nd}$, and $\mathrm{Nb}$ and minimum CPA values are recorded between 160 and $135 \mathrm{~cm}$ (Fig. 5). Noteworthy is that these elements do not show the drastic excursion of TOC and sand in $\sim 160 \mathrm{~cm}$ depth. Moreover, strong positive correlations $(R=\sim 0.8-0.9$; Additional file 2) are recorded between $\mathrm{Na}_{2} \mathrm{O}, \mathrm{K}_{2} \mathrm{O}, \mathrm{Zr}$, $\mathrm{Hf}, \mathrm{Nb}$, and $\mathrm{Nd}$ in this unit. This constellation changed abruptly at $\sim 15.7$ cal kyr BP, documented by the abrupt decrease of most lithogenic elements and their ratios. However, some proxies such as sand content, TOC, HI, and $\delta^{13} \mathrm{C}$ do not show such an abrupt change except Paq values, which decrease between 140 and $120 \mathrm{~cm}$ (Fig. 4).

$\mathrm{BC}$ which was partly very low in unit 1 , increased between 15.7 and 15.2 cal kyr BP (Fig. 4). The uppermost part of unit 2, (deposited between $\sim 14.4$ and $13.6 \mathrm{cal} \mathrm{kyr}$ BP $(90-71 \mathrm{~cm})$ is characterized by a distinct decrease in
TOC, HI, varying sand contents, absence of pyrite, and higher contents of terrestrial $n$-alkanes and BC (Fig. 4).

\subsection{Palynological results}

The pollen record is divided into five local pollen zones (LPZ 1-5; Figs. 6, 7) based on changes in the pollen spectra. No pollen was detected in unit 3 due to pedogenetic processes that disturbed pollen preservation. About 75 pollen taxa have been identified in the record. The green algae Botryococcus and Pediastrum attributed to the intermittent presence of a water body in the B4 depression, thus their palynological record reflects local conditions.

Poaceae $<37 \mu \mathrm{m}$ dominate the pollen spectra with values around $35 \%$. Other relatively common non-arboreal taxa are Artemisia, Chenopodiaceae/Amaranthaceae, Poaceae $>37 \mu \mathrm{m}$, and Plantago. The sum of arboreal pollen (AP) makes up around 15\% in LPZ 1-4 (from 250.5 to $90 \mathrm{~cm} ; 18.1-14.4 \mathrm{cal} \mathrm{kyr} \mathrm{BP})$ and increased to $38 \%$ during LPZ 5 (from 90 to $70 \mathrm{~cm} ; 14.3-13.6 \mathrm{cal} \mathrm{kyr} \mathrm{BP).} \mathrm{The} \mathrm{green}$ algae Botryococcus is most common in the lowest part of the record. Pediastrum increases with parallel decreases 




Fig. 4 Analytical properties of the B4 sediments, with depth profiles of the sand fraction (63-2000 $\mu \mathrm{m})$, total organic carbon (TOC), organic carbon-to-nitrogen ratio (TOC/N), Hydrogen Index (HI), $\delta^{13} \mathrm{C}$ values, Black Carbon (BC) and Paq. The light orange color shows dryer events while orange color indicates desiccation layers developed during Heinrich Event 1(H1). Blue color indicates the African Humid Period (AHP) and other humid episodes while dark green color indicates the event characterized as humid and arid according to pollen and geochemical results, respectively

of Botryococcus. Pollen of modern water plants, Potamogeton thunbergii and Ranunculus trichophyllus are not present in the fossil pollen record.

LPZ 1 (250.5-204 cm; 18.1-17.2 cal kyr BP) is characterized by Botryococcus maxima, which abruptly decreases at $17.3 \mathrm{cal}$ kyr BP and is replaced by high amounts of Pediastrum pollen (Fig. 7). Moreover, high percentages of Poaceae, herbs (non-arboreal pollen, NAP), Artemisia, and Chenopodiaceae/Amaranthaceae are recorded in LPZ1. Plantain (Plantago) has been very common. Arboreal pollen of Ericaceae, Podocarpus, Myrica, Juniperus, and Olea are found from the beginning of the archive.

LPZ 2 (204-194 cm; 17.2-16.9 BP) records an increase in Chenopodiaceae/Amaranthaceae and Plantago and strongly reduced occurrence of Artemisia and Pediastrum. Similarly, pollen percentage and pollen influx of Hagenia, Podocarpus, Myrica, Juniperus, and Olea show low values between 17.2 and $16.9 \mathrm{cal} \mathrm{kyr} \mathrm{BP.}$

LPZ 3 (194-110 cm, 16.9-15.2 cal kyr BP) starts with a subsequent increase of Podocarpus, Juniperus, and Olea from 194 to $177 \mathrm{~cm}(16.9-16.6 \mathrm{cal} \mathrm{kyr}$ BP) and a higher presence of Pediastrum. The afroalpine element, Alchemilla, which is highly underrepresented in the pollen record, is sporadically present from now on. The influx of Erica, Pediastrum, Hagenia, and Botryococcus pollen decrease between 165 and $155 \mathrm{~cm}$ (16.3 and $16.1 \mathrm{cal} \mathrm{kyr} \mathrm{BP})$, while Chenopodiaceae/Amaranthaceae pollen increase. Subsequently, higher Pediastrum values, more frequent fern spores, 




Fig. 5 XRF results of B4 sediments. Depth profiles of Zirconium ( $\mathrm{Zr}$ ), Sodium oxide ( $\left.\mathrm{Na}_{2} \mathrm{O}\right)$, Potassium oxide $\left(\mathrm{K}_{2} \mathrm{O}\right)$, Hafnium (Hf), Niobium ( $\mathrm{Nb}$ ), Zirconium/Rubidium (Zi/Rb), Zirconium/Silica oxide $\left(\mathrm{Zr} / \mathrm{SiO}_{2}\right)$, Zirconium/Titanium oxide $\left(\mathrm{Zr} / \mathrm{TiO}_{2}\right)$ and of the chemical proxy of alteration $\left(\mathrm{CPA}=\mathrm{Al}_{2} \mathrm{O}_{3} /\left(\mathrm{Al}_{2} \mathrm{O}_{3}+\mathrm{Na}_{2} \mathrm{O}\right)\right.$, inversed scale. The light orange color shows dryer events while orange color indicate desiccation layers developed during Heinrich Event $1(\mathrm{H} 1)$ and the hiatus. Blue color indicates the African Humid Period (AHP) and other humid episodes while dark green color indicates the event characterized as humid and arid according to pollen and geochemical results, respectively

and Sparganium-type are recorded between 155 and $135 \mathrm{~cm}$ (16.1 and $15.7 \mathrm{cal} \mathrm{kyr} \mathrm{BP).} \mathrm{A} \mathrm{lower} \mathrm{occurrence}$ of Erica pollen and the montane forest tree Hagenia recorded from 15.4 to $15.2 \mathrm{kyr} \mathrm{BP}$, while absolute values of montane forest taxa like Podocarpus and Juniperus increase. By contrast, Pediastrum, Plantago-type, and Grass pollen influx show high values.

LPZ 4 (110-90 cm, 15.2-14.4 cal kyr BP) records the most abundant Ericaceae and Podocarpus. Similarly, the sum of all arboreal pollen (AP) increases but does not exceed their former values. The same holds true for Artemisia. In contrast, the ratio of Chenopodiaceae/Amaranthaceae falls as low as never before. In consequence, the $\mathrm{A} / \mathrm{C}$ ratio increases strongly.

LPZ 5 (90-71 cm, 14.4-13.6 cal kyr BP) is marked by a strong expansion of Erica and Podocarpus. The previously significant elements Chenopodiaceae/Amaranthaceae and Plantago disappeared nearly completely, and Artemisia reduced strongly. Besides Poaceae, a wide range of Asteraceae (Senecio, Matricaria-type, Cichorioideae), which was present since the beginning of the record, became the most important vegetation constituents.

\section{Discussion}

\subsection{Radiocarbon dating}

Our radiocarbon ages show that depression B4 became ice-free at $\sim 18 \mathrm{cal} \mathrm{kyr} B \mathrm{BP}$ and thus records the climate, vegetation, and fire history from the end of the LGM to the Late Holocene. The timing of deglaciation $(18.2 \mathrm{cal}$ kyr BP) seems reliable, as the sediments are free of carbonates.

\subsection{Organic geochemistry}

Low TOC contents at the bottom of the profile (Fig. 4) mark cold conditions with low biomass production in, and around, the lake. TOC/N ratios are used to distinguish between terrestrial and aquatic carbon sources. Organic matter derived from algae usually shows TOC/ $\mathrm{N}$ values between 4 and 10 , while vascular land plants and terrestrial soil organic matter may have TOC/N ratios $>20$ (Meyers 1994) and $\sim 15$, respectively 

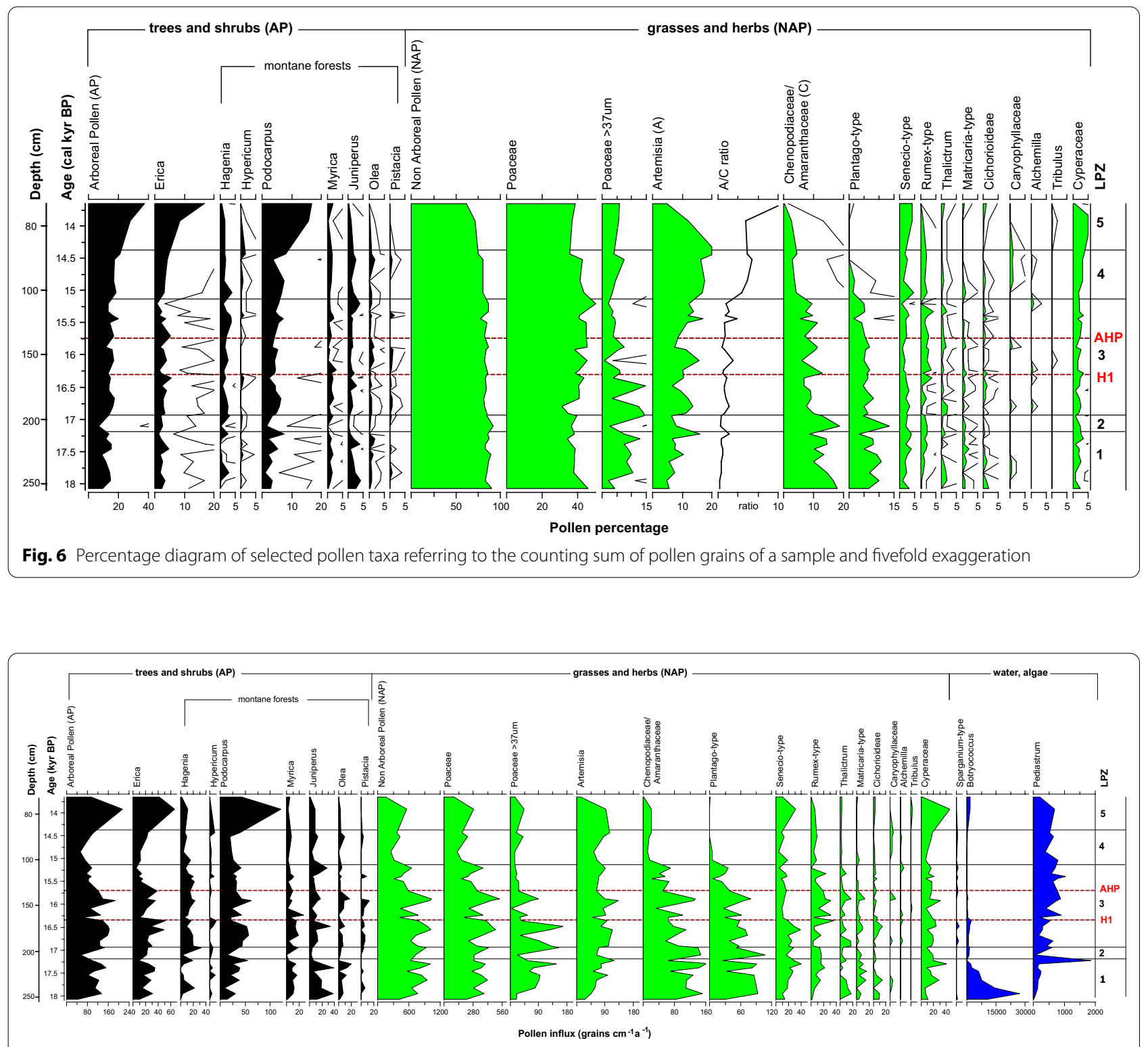



(Mekonnen et al. 2019). However, the use of TOC/N ratios as organic matter source indicators is highly constrained by degradation and mineralization, which results in low TOC/N values. TOC/N values of the B4 depression range between 3.5 and 12.3 , suggesting mainly primary lacustrine biomass production. According to Ficken et al. (2000), Paq values, between 0.4 and 1 characterize submerged and floating aquatic plants, while terrestrial plants yield values lower than 0.1 . Indeed, average $\mathrm{HI}$ values of $\sim 250$, together with elevated Paq values support the interpretation that mainly lacustrine primary biomass was produced under medium to high water levels, generating anoxic conditions in B4 depression. TOC values substantially decrease at $160 \mathrm{~cm}$ (16.3 cal kyr BP) accompanied by sand maxima. This likely documents an extremely low stand of the water table and the development of a desiccation surface. Increased sand input from the depression margins may take place because of temporary heavy rains during dry phases when the sparse vegetation cover protected less against erosion. Decreasing Paq values between 140 and $120 \mathrm{~cm}$ shows higher terrestrial input, likely due to higher rainfall intensities and accelerated erosion at the margins of the depression. Nevertheless, water levels dropped again already 
at 15.4 cal kyr BP as evidenced by the formation of a swamp around 15.4-15.2 cal kyr BP (120-110 cm; Fig. 4). Decreasing TOC and HI values and absence of pyrite in sediments deposited between 14.4 and 13.6 cal kyr BP indicate accelerated local desiccation, likely correlated with periodic sediment input. Varying sand contents suggest that humid and dry phases alternated, leading to deflation of small particles and organic matter, leaving behind sand in the depression. Intensive deflation and complete desiccation are likely responsible for the hiatus at $70 \mathrm{~cm}$ depth (13.6-10.2 kyr BP), coinciding with the transition from Late Glacial to Holocene.

Stable $C$ isotopes are frequently used in paleovegetation reconstructions due to their potential in discerning between C3 and C4 plants (Eshetu 2002; Glaser and Zech 2005). Our bulk $\delta^{13} \mathrm{C}$ values and those of long-chain $n$-alkanes show average values of $-14.3 \%$ and $-25.9 \%$, respectively. This might show $\mathrm{C} 4$ vegetation (Ficken et al. 2002; Glaser and Zech 2005) growing at the margin of the depression under relatively dry conditions during the Late Glacial. However, methanogenesis, assimilation of ${ }^{13} \mathrm{C}$-enriched $\mathrm{CO}_{2}$ and $\mathrm{HCO}_{3}{ }^{-}$by water plants due to long-lasting ice cover, especially during the early Late Glacial, and the low $\mathrm{CO}_{2}$ concentration in the atmosphere (Monnin et al. 2001) might have contributed to such positive $\delta^{13} \mathrm{C}$ values (Conrad et al. 2007). In contrast, modern plants from the surroundings of the lake show values indicating C3 vegetation. This result agrees with a study of Mekonnen et al. (2019), reporting that the modern vegetation in high altitudes of the Bale Mountains comprises only $\mathrm{C} 3$ plants.

$\mathrm{BC}$ produced by incomplete combustion of plant biomass is ubiquitous in lake sediments and glaciers (Glaser 1998). The weak BC maximum in the lowermost samples $(\sim 250 \mathrm{~cm})$ presumably reflects $\mathrm{BC}$ storage in glacier ice during the LGM, originating from atmospheric input. In contrast, high BC between 16.9 and $16.6 \mathrm{cal}$ kyr BP and between 15.7 and 14.4 cal kyr BP provides evidence for frequent fire events, likely due to increased amounts of combustible biomass under regionally wetter than under dry conditions.

\subsection{Inorganic geochemistry}

After deglaciation, the period between 18.1 and $16.6 \mathrm{cal}$ kyr BP started with the accumulation of electrolytepoor melting water in depression B4 (see EC in Additional file 1). The presence of pyrite at the bottom of the B4 profile implies a sedimentary environment with mainly anoxic conditions and sufficient organic matter that acts as a reductant and energy source for pyrite formation (Berner 1984). Due to their geochemical stability, lithogenic elements such as $\mathrm{Zr}, \mathrm{Hf}, \mathrm{Nb}$, and $\mathrm{Ti}$ are often used in paleoenvironmental studies as indicators of detrital and allochthonous input (Davies et al. 2015). For instance, $\mathrm{Zr}$ and $\mathrm{Zr}$ based ratios $(\mathrm{Zr} / \mathrm{Ti}, \mathrm{Zr} / \mathrm{Rb}, \mathrm{Zr} /$ $\mathrm{Al}$ ) are often used as proxies for aeolian input of Saharan dust (Jimenez-Espejo et al. 2014; Scheuvens et al. 2013; Moreno et al. 2006, and Hemming 2007), while $\mathrm{Si}$ ratios $(\mathrm{Ti} / \mathrm{Si}, \mathrm{Zr} / \mathrm{Si})$ are used as indicators of biogenic silica production during favorable seasons (Lamb et al. 2018; Davies et al. 2015; Brown et al. 2007). Furthermore, also $\mathrm{K}$ is used as an effective moisture fluctuation indicator (Foerster et al. 2012). In our B4 profile, lithogenic elements and ratios such as $\mathrm{Zr}, \mathrm{Hf}, \mathrm{Zr} / \mathrm{SiO}_{2}, \mathrm{Zr} / \mathrm{Rb}$, and $\mathrm{Zr} / \mathrm{TiO}_{2}$ show minimum values after deglaciation; they slightly increased around 210 and $190 \mathrm{~cm}(\sim 17.2$ and 16.9 cal kyr BP), while a continuous increase of these elements and ratios is recorded from 175 to $135 \mathrm{~cm}$ ( 16.6-15.7 cal kyr BP) (Fig. 5). In contrast, CPA values show a weak minimum at 210 and $190 \mathrm{~cm}$ and further decrease to $<80$ between 175 and $135 \mathrm{~cm}$. These results likely reflect intensified dry northerly winds (Brown et al. 2007; Marshall et al. 2011; Lamb et al. 2018; JimenezEspejo et al. 2014), which transported less weathered (low CPA, Na enriched, Fig. 5), allochthonous material in the Sanetti Plateau. The occurrence of gypsum-bearing layers in $\sim 210 \mathrm{~cm}(\sim 17.2 \mathrm{cal}$ kyr BP $)$ and between 166 and $152 \mathrm{~cm}(16.4-16.1 \mathrm{cal}$ kyr BP) show lower water tables and provide evidence for dry events. The latter is further confirmed by increasing values of $\mathrm{K}_{2} \mathrm{O}$ (Fig. 5), which agrees with results from Chew Bahir (Foerster et al. 2012). Moreover, increased values of $\mathrm{K}_{2} \mathrm{O}$ and $\mathrm{Na}_{2} \mathrm{O}$ (Fig. 5) coincide with the high abundance of Feldspar in $\sim 135 \mathrm{~cm}$ (Additional file 3), highlighting Feldspar containing allochthonous input. The abrupt decrease of most allochthonous elements and ratios (Fig. 5) at about 15.7 cal kyr BP indicates a drastic atmospheric reorganization with an abrupt decrease of dust inputs related to the beginning of the AHP, attributed to the northward migration of the rain belt and the ITCZ (Bastian et al. 2021).

\subsection{Palynology}

The green algae Botryococcus is generally found in tropical freshwater lakes under very cold environmental conditions (Jankovská and Komárek 2000). Therefore, the high occurrence of Botryoccoccus at the bottom of the B4 profile indicates deglaciation and discharge of cold meltwater into the lake. The abundant presence of Botroyoccocus, which is usually characterized by high TOC/N values of 18-36 (Last and Smol 2002; Bittner et al. 2020) and high $\delta^{13} \mathrm{C}$ values (Grice et al. 2001), may have contributed to the TOC/N increase recorded between 250 and $240 \mathrm{~cm}$ depth and positive $\delta^{13} \mathrm{C}$ values at the bottom of the profile (Fig. 4). This supports the interpretation of predominant lacustrine TOC production after 
deglaciation. The decrease of Botryococcus and a parallel increase of Pediastrum also show a relatively stable water body in the investigated depression.

The high percentages of Poaceae and herbs (non-arboreal pollen, NAP) between 18.1 and $17.2 \mathrm{cal}$ kyr BP documents open grass-land vegetation around the Sanetti Plateau. The high number of Artemisia and Chenopodiaceae/Amaranthaceae pollen indicate that the vegetation may have been steppe-like. The abundant presence of Plantago suggests a sparse vegetation cover with less competition shortly after deglaciation. However, the presence of arboreal pollen points to forests down the slopes of the Bale Mountains during the LGM. An increase in Chenopodiaceae/Amaranthaceae and Plantago and a decrease in Artemisia, Pediastrum, Hagenia, Podocarpus, Myrica, Juniperus, and Olea between $\sim 17.2$ and $16.9 \mathrm{cal} \mathrm{kyr} \mathrm{BP}$ reflect a reduction of the montane forests due to a 2300 -year interval with dry and/or cold climate. This interpretation further agrees with the mineralogical results which recorded a dry event between 17.2 and $16.9 \mathrm{cal}$ kyr BP. The increase of arboreal pollen and Pediastrum between about 16.9$16.6 \mathrm{cal}$ kyr BP marks a recovery of the montane forest and wetter local setting at the slopes of the Sanetti Plateau. At around 16.5 cal kyr BP, low values of Pediastrum, Erica, Hagenia, and Botryococcus indicate dry environmental conditions. The decrease in the influx of Erica pollen and subsequent increase of Chenopodeacea/Amaranthaceae around 16.3 cal kyr BP related to the desiccation phase of the B4 depression recorded by low TOC and high sand input. After this desiccation phase, a trend to locally more humid conditions is indicated by higher Pediastrum values, more frequent fern spores, and Sparganium-type between 155 and $135 \mathrm{~cm}$ (16.1 and $15.8 \mathrm{cal} \mathrm{kyr} \mathrm{BP})$. This is in agreement with increasing TOC values and it documents that on the SP the H1 stadial is characterized by a short-term desiccation, in contrast to the lowland archives (Fig. 8). Dry environmental conditions are also evidenced from 15.4 to $15.2 \mathrm{cal}$ kyr BP by the decrease in Erica and Hagenia pollen, while tolerant montane taxa such as Podocarpus and Juniperus survived. Nevertheless, as indicated by constant high Pediastrum influx and high Paq values, the B4 depression was partly or periodically flooded. Changes in seasonality and longer dry seasons may have given way to swamp formation. However, pollen types, including typical swamp and water plants (Cyperaceae, Sparganium-type), show no increase. The increasing Plantago-type includes the amphibious species Littorella uniflora, but this swamp species is not known from Africa today (Hoggard et al. 2003). Possibly, the increased Poaceae influx marks the spreading of swamp grasses at the site. A temporary decrease in the influx of arboreal pollen may be related to a short cold event that also decreased the flourishing of grasses and herbs (NAP). The long-time trend in NAP influx reduction can relate to a change in the vegetation from wind-pollinated plant groups (Poaceae, Chenopodiaceae/Amaranthaceae, Plantago-type, Rumex-type) to insect-pollinated taxa (Senecio-type, Caryophyllaceae), leading to an overall reduced NAP pollen input. By contrast, the decrease in Chenopodiaceae/Amaranthaceae and consequent increase of $\mathrm{A} / \mathrm{C}$ between 15.2 and $14.4 \mathrm{cal}$ kyr BP indicate the most humid conditions regionally, whereas locally the B4 depression started to dry out due to increased silting up. A significant increase in Erica and Podocarpus pollen between 14.4 and $13.6 \mathrm{cal}$ kyr BP substantiates the expansion of the Ericaceous belt and the lowland forests, together with a fundamental change in vegetation composition on the Sanetti Plateau. This is in contrast to the sedimentological results which document progressive local drying out. This discrepancy might be due to the potential of pollen assemblage to provide regional environmental signals, while biogeochemical proxies (Fig. 4), mainly reflect the local conditions of the $\mathrm{B} 4$ record.

\section{Environmental implications and comparison with other records}

\subsection{Deglaciation and climate fluctuations}

${ }^{14} \mathrm{C}$ ages from the lower sediment of depression B4 suggest that the Sanetti Plateau became at least locally, icefree already at 18.2 cal kyr BP. Surface exposure dating of erratic boulders in $\mathrm{N}$-exposed valleys and on the Sanetti Plateau suggest the onset of deglaciation at $15.2 \pm 1.2 \mathrm{cal}$ kyr BP (Groos et al. 2021; Ossendorf et al. 2019). The basal ${ }^{14} \mathrm{C}$-age of Garba Guracha sediments $(15.9-16.7 \mathrm{cal}$ kyr BP) is almost in agreement with the age of deglaciation estimated from cosmogonic ages (Umer et al. 2007; Tiercelin et al. 2008; Bittner et al. 2020). This discrepancy might be due to the ice cover in the $N$-exposed trough valley of Lake Garba Guracha that might have been thicker and thus longer lasting than on the Plateau around the B4 profile, which is strongly wind-exposed and has no ice accumulating catchment (Fig. 1). Besides, methodological uncertainties (exposure dating versus radiocarbon analysis) cannot be ruled out. Nevertheless, the deglaciation age of B4 depression seems reliable.

Our palynological and biogeochemical results record climate fluctuations on the Sanetti Plateau since the end of the LGM. Disregarding the initial phase around $18 \mathrm{cal}$ kyr BP, the environmental conditions during unit 1 can be characterized as predominantly lacustrine, correlating with results from Lake Tanganyika, Challa, and Chew Bahir, which also show predominantly humid conditions (Fig. 8). However, between $\sim 17.2$ and 16.9 cal kyr BP partly fluctuating allochthonous elements (Fig. 5), correlating with increased deflation in the northerly dust source areas, and an increase in Chenopodiaceae/Amaranthaceae and reduction in montane forest indicate 
a short dry event during this time. Possibly, this event relates to a short weakening of the East-Asian monsoon system as reported by Wang et al. (2001) for Asia around $17 \mathrm{cal}$ kyr BP as a precursor of Heinrich Event 1 (Hemming 2004). Also, Camuera et al. (2021) described such an early H1 phase (refers to HS1b) between $17.2-16.9 \mathrm{cal}$ kyr BP in the Mediterranean. The 300 years of climate deterioration are also weakly documented in sediments of Chew Bahir (Fig. 8) and might be part of the megadrought postulated for the Afro-Asian monsoon system between 17-16 cal kyr BP (Stager et al. 2011).

We interpret increasing input of allochthonous elements between 16.6 and ca.15.9 cal kyr BP (Fig. 5) as an indicator of the dominance of northerly wind, correlated with progressive ecosystem degradation in the lowlands, and occurring contemporaneously with the North Hemispheric cooling during H1. Interestingly, on the Sanetti Plateau TOC-minima and sand-maxima indicate only short-term intensive desiccation at $16.3 \mathrm{cal} \mathrm{kyr} \mathrm{BP}$, and already between $\sim 16.1$ and $15.7 \mathrm{cal} \mathrm{kyr} \mathrm{BP} \mathrm{TOC}$ and HI increased again, whereas sand contents rapidly decreased (Fig. 4), reflecting that the environmental conditions locally, on the Sanetti Plateau improved, in agreement with the palynological results. This discrepancy between the high altitudes of the Sanetti Plateau and the vast lowlands northerly might reflect that the Bale Mountains, located close to the Indian Ocean, react more rapidly to environmental changes, whereas the lowland ecosystems are much more resilient, due to slow negative vegetation and monsoon feedbacks.

In many studies, arid conditions in tropical Africa between $\sim 16.8$ and 15.4 cal kyr BP were already described, coinciding with $\mathrm{H} 1$ (e.g. Bonnefille and Chalie 2000; Gasse 2000; Talbot and Lærdal 2000; Hemming 2004; Tiercelin et al. 2008; Tierney et al. 2008). Lamb et al. (2007) also mentioned an "episode of shallow water" in the Lake Tana basin between 16.7 and $15.7 \mathrm{cal} \mathrm{kyr} \mathrm{BP.}$ Based on $\delta \mathrm{D}$ values of higher plant leaf waxes from Lake Challa (Fig. 8), Tierney et al. (2011) concluded that these arid conditions in eastern Africa were due to reduced moisture input from the Indian Ocean. Previous studies described that climatic fluctuations in eastern Africa during the Late Quaternary were related to teleconnections between North Atlantic cooling events, recorded in Greenland ice cores and $N$-Atlantic sediments, and the weakening of the Indian Summer Monsoon (Tierney et al. 2008; Marshall et al. 2011; Mohtadi et al. 2014; Lamb et al. 2018). It is suggested that during these cooling events, caused by massive iceberg surges and cold meltwater entering the North Atlantic, the ITCZ and the Northern Hemisphere westerlies shifted abruptly southwards and abruptly northward at the end of the cooling, thus controlling deflation of lithogenic elements out of the northern source areas and their input in the surrounding areas (Tierney et al. 2008; Marshall et al. 2009; Lamb et al. 2018). This might explain the high input of allochthonous lithogenic elements (Fig. 5). A similar finding is presented by Brown et al. (2007), reporting elevated inputs of e.g. $\mathrm{Zr}$ to Lake Malawi due to intensified northerly winds.

The allochthonous elements decreased abruptly at about $15.7 \mathrm{cal}$ kyr BP, likely correlating with the onset of the AHP, and evoked by rapid northward migration of the rain belt and the ITCZ in relation to precession-driven insolation changes (Bastian et al. 2021). We assume that this resulted in a relatively rapid establishment of a denser vegetation cover and a drastic reduction of dust deflation from northern source areas (Figs. 5 and 8). The timing of this event agrees with the results of Camuera et al. (2021). They concluded that the AHP started in the Mediterranean at $15.7 \mathrm{cal} \mathrm{kyr} \mathrm{BP}$ after the termination of HS1c. Also, Lamb et al. (2007, 2018), described such an abrupt shift from Lake Tana, and Marshall et al. (2011) dated this event to $15.3 \mathrm{cal}$ kyr BP. In Lake Victoria, the rapid refilling of the basin is dated to $14.5 \mathrm{cal}$ kyr BP (Talbot and Lærdal 2000). One reason for this discrepancy might be dating uncertainties. However, our data from the B4 profile let assume that locally, at the high altitudes of the Sanetti Plateau, the abrupt onset of humidity might have started almost 1000 years before the onset of the Bølling-Allerød warming in the North-Atlantic region (Alley and Clark 1999; Van Raden et al. 2013) and before at least some hundred years earlier than in Lake Tana region, located $630 \mathrm{~km}$ northward. In contrast to the sedimentological and geochemical results, our pollen results (Figs. 6 and 7) do not show clear evidence for this abrupt start of the AHP. Within this humid period, water levels in the B4 record did not remain high but lowered already around $15.4 \mathrm{cal}$ kyr BP, and a swamp developed, reflecting probably higher evaporation and less precipitation.

(See figure on next page.)

Fig. 8 A summary figure comparing palynological and biogeochemical results from unit 1 and unit 2 of the B4 sediments with relevant proxies from Lake Tanganyika (Tierney et al. 2008), Lake Challa (Tierney et al. 2011) and Lake Chew Bahir (Foerster et al. 2012) sediments. Light orange color indicate dryer events, orange color indicates a desiccation layer developed during Heinrich Event 1 ( $\mathrm{H} 1$ ). Blue color characterizes the African Humid Period (AHP) and other humid episodes while dark green color indicates the event characterized as humid and arid according to pollen and geochemical results, respectively. $\delta D$ and $K$ values are in inversed scale 


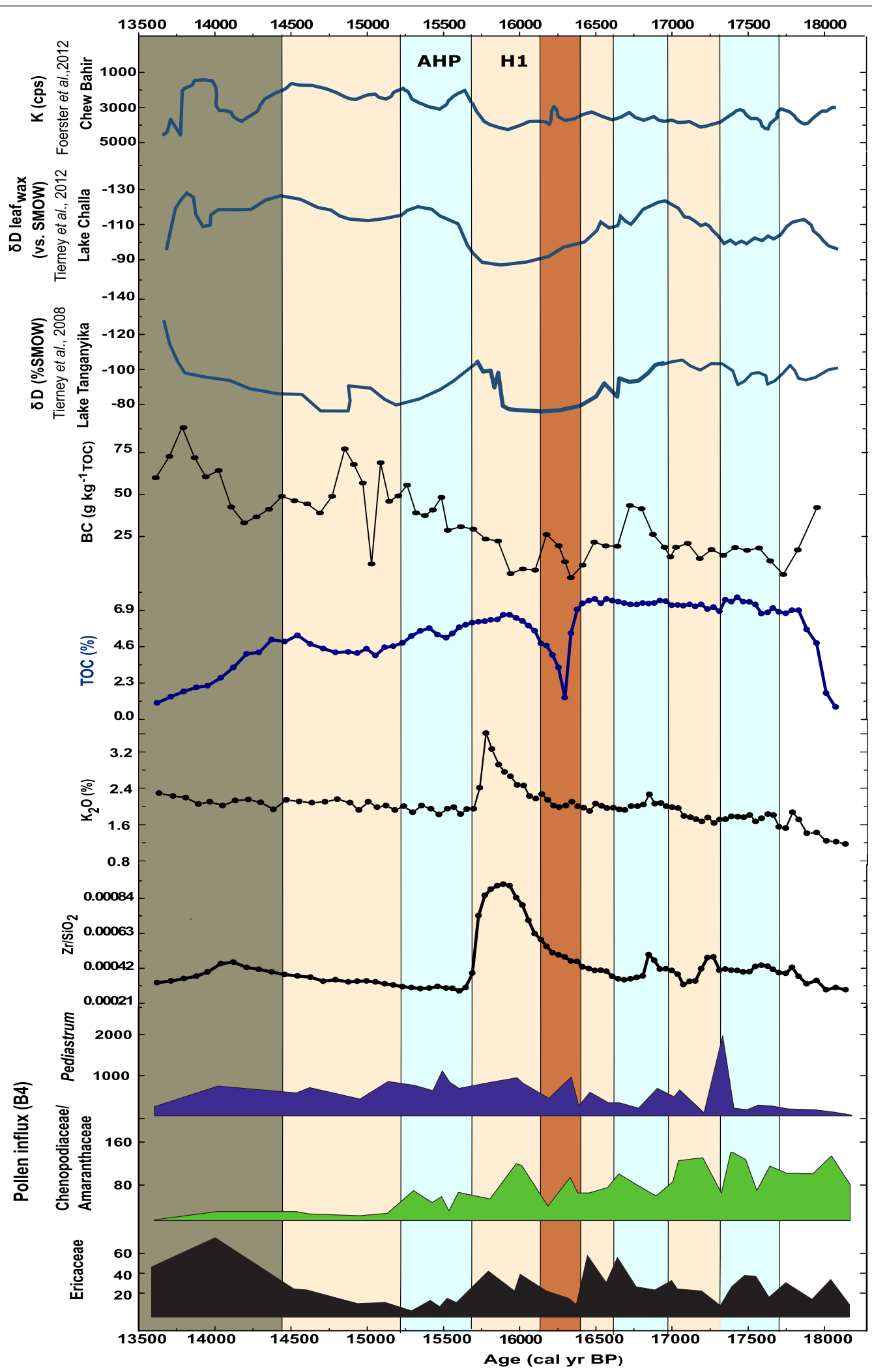

Fig. 8 (See legend on previous page.) 
A similar finding was reported from Lake Tana, where a papyrus swamp developed between 15.7 and $15.1 \mathrm{cal} \mathrm{kyr}$ $\mathrm{BP}$, due to lower lake levels and reduced rainfall (Lamb et al. 2007). Slightly rising allochthonous proxies (e.g. $\mathrm{Zr}, \mathrm{Nb}, \mathrm{Hf}$, see Fig. 5) likely document progressive local drying-up after about 14.4 cal kyr BP, whereas ascending arboreals indicate regional wetter conditions (Fig. 7). The uppermost part of the unit 2 sediments, deposited between 14.4-13.6 cal kyr BP, is enriched in arboreal pollen, reflecting regional wetting; but fluctuating sand contents and higher input of terrestrial alkanes let assume that drying-up of the B4 depression by advanced periodic sediment input continued. These processes do not allow a reliable correlation of the environmental dynamics affecting the Sanetti Plateau with those documented in sediments of Lake Tanganyika, Challa, and Chew Bahir (Fig. 8); also an unambiguous relationship with climatic phenomena known from the North Atlantic region (e.g. Allerød) cannot be identified in the upper part of unit 2 .

\subsection{Vegetation}

The B4 pollen record allows the reconstruction of vegetation changes from 18.1 to $13.6 \mathrm{cal}$ kyr BP. Between 18.1 and $16.8 \mathrm{cal}$ kyr BP, the vegetation is characterized as herb-rich grassland with Chenopodiaceae/Amaranthaceae. Plantago maxima between 17.2-16.9 cal kyr BP are related to dry and/or cold environmental conditions (see Section 4.4). These results are roughly in agreement with Umer et al. (2007), reporting open grassland vegetation at 16 cal kyr BP around Lake Garba Guracha. Our pollen record further shows high Arboreals such as Podocarpus, Hygenia, Erica, and Juniperus at 16.9 cal kyr BP, indicating more favorable conditions, in agreement with the sedimentological data. Increased aridity between 16.6 and 15.7 cal kyr BP, well documented by most biogeochemical proxies and interpreted to correlate with $\mathrm{H} 1$, is not clearly revealed in the palynological data. The desiccation surface developed around 16.3 cal kyr BP correlates with decreased contents of Erica pollen, Pediastrum, ferns, and Botryococcus, and elevated Chenopodiaceae/Amaranthaceae ratios, indicating a temporary phase of less favorable, drier environmental conditions. This possibly marks the time of maximum $\mathrm{H} 1$ dryness. Similarly, the AHP, recorded by biogeochemical proxies, is not obvious in the pollen results. Our data show that Ericaceae pollen content considerably increased on the Sanetti Plateau from 14.4 to 13.6 cal kyr BP, likely correlating with an increase in temperature, which might be synchronous with the European Meiendorf interstadial starting at 14.4 varve years (Litt et al. 2001). According to pollen results from Lake Garba Guracha and peat deposits, Umer et al. (2007) and Kuzmicheva et al. (2014) assume that Erica vegetation expanded on the Sanetti Plateau above the actual upper limit of the Erica belt, only during the early Holocene beginning at $11.2 \mathrm{cal}$ kyr BP. The dry climate during mid to Late Holocene and natural and/or human-induced fires (Miehe and Miehe 1994) are suggested as major causes for the decline of Erica which at present exists above the upper line of the Erica belt only in form of isolated fragments, mainly restricted to slopes rich in basalt boulders. Furthermore, Miehe and Miehe (1994) assumed that these Erica patches are relics that document an intensive extension of Erica species on the Sanetti Plateau after deglaciation, which were later on destroyed because of the invasion of hunter-gatherers and pastoralists. However, since the upper timberline is temperature-controlled (Körner 2008), we hypothesize these Erica patches on the plateau survive due to better microclimate, generated by dark basalt boulders.

\subsection{Fire dynamics on the Sanetti Plateau}

Our black carbon results (Fig. 4) show that fire was a common phenomenon in the Bale Mountains even during the early Late Glacial. However, pollen data indicate that at this time Erica was not growing around the B4 depression (Fig. 8). Therefore, BC in the lower part of the $\mathrm{B} 4$ profile likely originates from other vegetation fires or the Erica belt in lower altitudes. This interpretation is supported by the fact that $\mathrm{BC}$, even in the dry mode $\mathrm{H} 1$ sediments, is not clearly increased. Only with the beginning of the AHP around 15.7 cal kyr BP, BC started to increase, correlating with warmer and more humid environmental conditions, and reaching a maximum at about 15 cal kyr BP coinciding with increasing Erica pollen. In the uppermost part of unit $2(70-80 \mathrm{~cm})$ Erica pollen further increased, again correlating with maximum $\mathrm{BC}$ at about $13.6 \mathrm{cal}$ kyr BP.

Up to now, despite the human invasion during 47-31 cal kyr BP, there is no evidence that during the Late Glacial hunter-gatherers were living on the plateau and burned the Erica to facilitate hunting. However, we cannot rule out that fires were triggered by the increase of easily combustible Erica biomass due to improved environmental conditions. For a different time period, but in connection with the fuel-controlled fire process, the charcoal record from Garba Guracha supports a strong correlation between fire occurrence and heathland expansion during the Holocene (Gil-Romera et al. 2019). Elevated BC in the early humid Holocene deposits of the B4 record (not shown here) supports our interpretation that the burning of Erica is mainly controlled by the amount of Erica biomass, being higher under warm and humid climates. 


\section{Conclusions}

Our high altitude sedimentary archive provides a new older deglaciation age of 18.2 cal kyr BP for the Sanetti Plateau. Biogeochemical results show that the Plateau was sensitive to local, regional and global climate changes. We detected a severe local drought event on the Sanetti Plateau at 16.3 cal kyr BP with complete desiccation of the past B4 lake for some decades, related to H1. Between 16.6 and $15.7 \mathrm{cal}$ kyr BP allochthonous elements like $\mathrm{Zr}, \mathrm{Hf}, \mathrm{Nd}, \mathrm{Nb}, \mathrm{Na}$, presumably windblown by dry northerly winds during H1, accumulated increasingly in the B4 record, indicating continuous but delayed degradation of the wind source areas in lower altitudes but without documenting maximum dryness at $16.3 \mathrm{cal}$ kyr BP. This is in contrast to our high altitude B4 archive and reflects the resilience of the lowland ecosystems. The Abrupt change to humid conditions at $\sim 15.7 \mathrm{cal} \mathrm{kyr}$ BP indicates the onset of AHP in the Bale Mountains some hundred years earlier than in the Lake Tana region but in agreement with the termination of the HS1c phase in the Mediterranean.

The vegetation on the Sanetti Plateau was less sensitive to increased aridity during $\mathrm{H} 1$ and also to increased humidity during AHP. Nevertheless, the Erica pollen increased in the B4 sediments at $\sim 14.4 \mathrm{cal}$ kyr BP, correlating with a wet and warm regional climate. Despite this increase, it remains open whether the Ericaceous belt expanded to the plateau during that time or during the early Holocene, except for the currently existing isolated patches on boulder-rich steep slopes. Our results indicate that fire incidences mainly coincide with an expansion of the vegetation cover and less with dry periods. Most likely, a warm and humid climate promotes biomass production of Erica, hence increasing the amount of fuel, which burns from time to time. This allows to conclude that biomass and thus fuel availability is important factor controlling fire events in the Bale Mountains.

\section{Abbreviations \\ AHP: African humid period; A/C: Artemisia/Chenopodiaceae; AP: Arboreal pollen; BC: Black carbon; BPCAs: Benzene polycarboxylic acids; CPA: Chemical proxy of alteration; DCM: Dichloromethane; FID: Flame ionization detector; GC: Gas chromatography; H1: Heinrich event 1; HI: Hydrogen index; LGM: Last Glacial Maximum; NPA: Non-arboreal pollen; XRF: X-ray fluorescence; YD: Younger Dryas.}

\section{Supplementary Information}

The online version contains supplementary material available at https://doi. org/10.1186/s40645-022-00472-9.

Additional file 1. Grain size distribution (clay $<6.3 \mu \mathrm{m}$, silt $6.3-63 \mu \mathrm{m}$ and sand 63-2000 $\mu \mathrm{m}$ ), electrical conductivity (EC), $\mathrm{pH}$, and depth profiles of $\mathrm{SiO}_{2}$ of the $\mathrm{B} 4$ sediments. Light orange color indicates drier event while orange color indicates desiccation during $\mathrm{H} 1$ and the hiatus. Blue colors characterize the AHP and other humid episodes while dark green color indicate the event characterized as humid and arid according to pollen and geochemical results, respectively.

Additional file 2. PCA biplot results based on geochemical compounds of the B4 sediments in unit 1 and unit 2. In this figure $63.5 \%$ of variance is explained (component $1=45.5 \%$ and component $2=18 \%$ ). The two ellipses show the cluster of our samples based on the stratigraphic units. The arrows indicate each proxy and the distance between each arrow exhibits the strength of the correlation between elements and compounds. While $\mathrm{SiO}_{2}, \mathrm{MnO}_{1} \mathrm{P}_{2} \mathrm{O}_{5}$ and $\mathrm{Ba}$ contents are high in unit 1, unit 2 is characterized by high $\mathrm{Zr}, \mathrm{Hf}, \mathrm{Sm}, \mathrm{Nd}, \mathrm{Ce}, \mathrm{Y}$ and $\mathrm{Na}_{2} \mathrm{O}$ values. However, $\mathrm{MgO}, \mathrm{Al}_{2} \mathrm{O}_{3}, \mathrm{TiO}_{2}, \mathrm{Cu}, \mathrm{Cr}, \mathrm{Rb}$, Sr, Sc etc. are very low in both units.

Additional file 3. A table showing mineralogical results of selected samples from the B4 profile.

\section{Acknowledgements}

We are grateful to the Bale Mountains National Park and Ethiopian Wild Life Conservation Authority for permitting the scientific fieldwork and facilitating access to sample materials used in this study. We express our gratitude to the Department of Plant Biology and Biodiversity Management, Addis Ababa University, for scientific collaboration. We also extend our sincere thanks to M. Heider, M. Benesch, and $\mathrm{H}$. Maennicke for their generous help during laboratory work and J. Feilner for his help with the drawing. B. Mekonnen acknowledges the support given by the Katholischer Akademischer Ausländer-Dienst (KAAD). We kindly thank three anonymous reviewers for their constructive comments and suggestions that highly helped to improve our manuscript.

\section{Authors' contributions}

WZ and BG proposed the topic, conceived and designed the study. Fieldwork (sample collection) was done by WZ, DS, RZ and AM. BM, FS, RB and AA did the laboratory work and BM prepared the manuscript with the help of WZ, FS and BG. All co-authors contributed to, read and approved the manuscript.

\section{Funding}

Open Access funding enabled and organized by Projekt DEAL. This work was carried out within the DFG-funded Research Unit 2358, "The Mountain Exile Hypothesis" (Grant Nos. GL327/18-1, ZE154/70-1).

\section{Availability of data and materials}

The datasets supporting the conclusions of this article are available in the following Zenodo repository: https://doi.org/10.5281/zenodo.4767156.

\section{Declarations}

\section{Competing interests}

The authors declare that they have no competing interest.

\section{Author details}

${ }^{1}$ Institute of Agricultural and Nutritional Sciences, Soil Biogeochemistry, Martin Luther University Halle-Wittenberg, Halle, Germany. ${ }^{2}$ Department of Urban Agriculture, Misrak Polytechnic College, Addis Ababa, Ethiopia. ${ }^{3}$ Institute of Geography, Friedrich-Schiller-University Jena, Jena, Germany. ${ }^{4}$ Institute of Geography, Technische Universität Dresden, Dresden, Germany. ${ }^{5}$ Lower Saxony Institute for Historical Coastal Research, Wilhelmshaven, Germany. ${ }^{6}$ Department of Palynology and Climate Dynamics, Albrecht-Von-Haller Institute for Plant Sciences, Gottingen University, Göttingen, Germany. ${ }^{7}$ Institute of Applied Geosciences, TU Berlin, Berlin, Germany. ${ }^{8}$ Department of Natural Resource Management, Jigjiga University, Jigjiga, Ethiopia. ${ }^{9}$ Department of Geo-Environmental Processes and Global Change, Pyrenean Institute of Ecology, CSIC, Zaragoza, Spain. ${ }^{10}$ Department of Plant Biology and Biodiversity Management, Addis Ababa University, Addis Ababa, Ethiopia. ${ }^{11}$ International Livestock Research Institute, Addis Ababa, Ethiopia. ${ }^{12}$ Department of Soil Science, University of Bayreuth, Bayreuth, Germany.

Received: 18 May 2021 Accepted: 9 February 2022

Published online: 25 February 2022 


\section{References}

Alley RB, Clark PU (1999) The deglaciation of the northern hemisphere: a global perspective. Annu Rev Earth Planet Sci 27:149-182

Antoine P, Rousseau D-D, Moine O, Kunesch S, Hatte C, Lang A, Tissoux H, Zoller L (2009) Rapid and cyclic aeolian deposition during the Last Glacial in European loess: a high-resolution record from Nussloch, Germany. Quat Sci Rev 28:2955-2973. https://doi.org/10.1016/j.quascirev.2009.08. 001

Bastian L, Mologni C, Vigier N, Bayon G, Lamb H, Bosch D, Kerros ME, Colin C, Revel M (2021) Co-variations of climate and silicate weathering in the Nile Basin during the Late Pleistocene. Quat Sci Rev 264:107012. https://doi. org/10.1016/j.quascirev.2021.107012

Berner RA (1984) Sedimentary pyrite formation: an update. Geochim Cosmochim Acta 48(4):605-615. https://doi.org/10.1016/0016-7037(84)90089-9

Beug HJ. Pollen profile from site Kolbermoor5, Rosenheim, Oberbayern, Germany, Pangaea. 2004. https://doi.org/10.1594/PANGAEA.142583.

Billi P (2015) Geomorphological landscapes of Ethiopia. In: Billi P (ed) Landscapes and landforms of Ethiopia. Springer, pp 3-32. https://doi.org/10. 1007/978-94-017-8026-1_1

Bittner L, Bliedtner M, Grady D, Gil-Romera G, Martin-Jones C, Lemma B, Mekonnen B, Lamb HF, Yang H, Glaser B, Szidat S, Salazar G, Rose NL, Opgenoorth L, Miehe G, Zech W, Zech M (2020) Revisiting afro-alpine Lake Garba Guracha in the Bale Mountains of Ethiopia: rationale, chronology, geochemistry, and paleoenvironmental implications. J Paleolimnol. https://doi.org/10.1007/s10933-020-00138-w

Blaauw M, Christen JA (2011) Flexible paleoclimate age-depth models using an autoregressive gamma process. Bayesian Anal 6(3):457-474. https:// doi.org/10.1214/11-BA618

Bonnefille R, Chalie F (2000) Pollen-inferred precipitation time-series from equatorial mountains, Africa, the last $40 \mathrm{kyr}$ BP. Glob Planet Change 26(1-3):25-50. https://doi.org/10.1016/S0921-8181(00)00032-1

Bonnefille R, Mohammed U (1994) Pollen-inferred climatic fluctuations in Ethiopia during the last 3000 years. Palaeogeogr Palaeoclimatol Palaeoecol 109(2-4):331-343. https://doi.org/10.1016/0031-0182(94)90183-X

Brodowski S, Rodionov A, Haumaier L, Glaser B, Amelung W (2005) Revised black carbon assessment using benzene polycarboxylic acids. Org Geochem 36(9):1299-1310. https://doi.org/10.1016/j.orggeochem.2005 03.011

Brown ET, Johnson TC, Scholz CA, Cohen AS, King JW (2007) Abrupt change in tropical African climate linked to the bipolar seesaw over the past 55,000 years. Geophys Res Lett 34:1-5. https://doi.org/10.1029/2007GL031240

Buggle B, Glaser B, Hambach U, Gerasimenko N, Marković S (2011) An evaluation of geochemical weathering indices in loess-paleosol studies. Quat Int 240(1-2):12-21. https://doi.org/10.1016/j.quaint.2010.07.019

Bussmann RW (1997) The forest vegetation of Harenna escarpment (Bale Province, Ethiopia) — syntxomomy and phytogeographical affinities. Phytocoenologia 1(27):1-23

Camberlin P (2018) Climate of Eastern Africa. Oxford research Encyclopedia of climate science. Oxford University Press

Camuera J, Jiménez-Moreno G, Ramos-Román MJ, García-Alix A, JiménezEspejo FJ, Toney JL, Anderson RS (2021) Chronological control and centennial-scale climatic subdivisions of the Last Glacial Termination in the western Mediterranean region. Quat Sci Rev 255(March):106814. https://doi.org/10.1016/j.quascirev.2021.106814

Conrad R, Chan OC, Claus P, Casper P (2007) Characterization of methanogenic Archaea and stable isotope fractionation during methane production in the profundal sediment of an oligotrophic lake (Lake Stechlin, Germany). Limniology Oceanogr 54(2):1-14

Costa K, Russell J, Konecky B, Lamb H (2014) Isotopic reconstruction of the African Humid Period and Congo Air Boundary migration at Lake Tana, Ethiopia. Quat Sci Rev 83:58-67. https://doi.org/10.1016/j.quascirev.2013. 10.031

Davies SJ, Lamb HF, Roberts SJ (2015) Micro-XRF core scanning in palaeolimnology: recent developments, micro-XRF. Springer

Eshetu Z (2002) Historical C3-C4 vegetation pattern on forested mountain slopes: its implication for ecological rehabilitation of degraded highlands of Ethiopia by afforestation. J Trop Ecol 18(5):743-758. https://doi.org/10. 1017/S0266467402002481

Ficken KJ, Li B, Swain DL, Eglinton G (2000) An n-alkane proxy for the sedimentary input of submerged/floating freshwater aquatic macrophytes. Org Geochem 31:745-749. https://doi.org/10.1038/nmat4240
Ficken KJ, Wooller MJ, Swain DL, Street-Perrott FA, Eglinton G (2002) Reconstruction of a subalpine grass-dominated ecosystem, Lake Rutundu, Mount Kenya: a novel multi-proxy approach. Palaeogeogr Palaeoclimatol Palaeoecol 177(1-2):137-149. https://doi.org/10.1016/S0031-0182(01) 00356-X

Foerster V, Foerster V, Junginger A, Langkamp O, Gebru T, Asrat A (2012) Climatic change recorded in the sediments of the Chew Bahir basin, Southern Ethiopia, during the last 45,000 years Climatic change recorded in the sediments of the Chew Bahir basin, southern Ethiopia, during the last 45,000 years. Quat Int 274:25-37. https://doi.org/10.1016/j.quaint. 2012.06.028

Friis I (1986) Zonation of forest vegetation on the south slope of Bale Mountains, South Ethiopia. Ethiop J Sci 9(12):29-44

Gasse F (2000) Hydrological changes in the African tropics since the Last Glacial Maximum. Quat Sci Rev 19:189-211

Gil-Romera G, Adolf C, Benito BM, Bittner L, Johansson MU, Grady DA, Lamb HF, Lemma B, Fekadu M, Glaser B, Mekonnen B, Sevilla-Callejo M, Zech M, Zech W, Miehe G (2019) Long-term fire resilience of the Ericaceous Belt, Bale Mountains, Ethiopia. Biol Lett 15(7):20190357. https://doi.org/10. 1098/rsbl.2019.0357

Glaser B, Zech W (2005) Reconstruction of climate and landscape changes in a high mountain lake catchment in the Gorkha Himal, Nepal during the Late Glacial and Holocene as deduced from radiocarbon and compound specific stable isotope analysis of terrestrial, aquatic and microbi. Org Geochem 36:1086-1098. https://doi.org/10.1016/j.orggeochem.2005.01. 015

Glaser B, Haumaier L, Guggenberger G, Zech W (1998) Black carbon in soils: the use of benzenecarboxylic acids as specific markers. Org Geochem 29(4):811-819. https://doi.org/10.1016/S0146-6380(98)00194-6

Gosling WD, Miller CS, Livingstone DA (2013) Atlas of the tropical West African pollen flora. Rev Palaeobot Palynol 199:1-135. https://doi.org/10.1016/j. revpalbo.2013.01.003

Grice K, Audino M, Boreham CJ, Alexander R, Kagi RI (2001) Distributions and stable carbon isotopic compositions of biomarkers in torbanites from different palaeogeographical locations. Org Geochem 32(10):1195-1210. https://doi.org/10.1016/S0146-6380(01)00087-0

Groos AR, Akçar N, Yesilyurt S, Miehe G (2021) Nonuniform Late Pleistocene glacier fluctuations in tropical Eastern Africa. Sci Adv. https://doi.org/10. 1126/sciadv.abb6826

Hailemariam SN, Soromessa T, Teketay D (2016) Land use and land cover change in the bale mountain eco-region of Ethiopia during 1985 to 2015 Land 5(4):41. https://doi.org/10.3390/land5040041

Hedberg O (1951) Vegetation belts of the East African Mountains. Results of the Swedish East African expedition. Sven Bot Tidskr 45:1-144

Hemming SR (2004) Heinrich events: massive late pleistocene detritus layers of the North Atlantic and their global climate imprint. Rev Geophys. https:// doi.org/10.1029/2003RG000128.1

Hemming SR (2007) Terrigenous sediments. In: Elias SA (ed) Encyclopedia of quaternary science, vol 3. Elsevier, pp 1776-1785

Herzschuh U (2007) Reliability of pollen ratios for environmental reconstructions on the Tibetan Plateau. J Biogeogr 34(7):1265-1273. https://doi.org/ 10.1111/j.1365-2699.2006.01680.x

Hillman JC (1986) Conservation in Bale Mountains National Park, Ethiopia. Oryx 20(2):89-94. https://doi.org/10.1017/S0030605300026314

Hillman JC (1988) The Bale Mountains National Park Area, Southeast Ethiopia, and its management. Mt Res Dev 8(2):253-258

Hoggard RK, Kores PJ, Molvray M, Hoggard GD, Broughton DA (2003) Molecular systematics and biogeography of the amphibious genus Littorella (Plantaginaceae). Am J Bot 90(3):429-435. https://doi.org/10.3732/ajb. 90.3.429

Jan F, Schüler L, Behling H (2015) Trends of pollen grain size variation in C3 and C4 Poaceae species using pollen morphology for future assessment of grassland ecosystem dynamics. Grana 54(2):129-145. https://doi.org/10. 1080/00173134.2014.966754

Jankovská V, Komárek J (2000) Indicative value of Pediastrum and other coccal green algae in palaeoecology. Folia Geobot 35(1):59-82. https://doi.org/ 10.1007/BF02803087

Jimenez-Espejo FJ et al (2014) Saharan aeolian input and effective humidity variations over western Europe during the Holocene from a high altitude record. Chem Geol 374-375:1-12 
Juggins S (2007) C2 user guide. Software for ecological and palaeoecological data analysis and visualisation. University of Newcastle

Kidane Y, Stahlmann R et al (2012) Vegetation dynamics, and land use and land cover change in the Bale Mountains, Ethiopia. Environ Monit Assess 184(12):7473-7489. https://doi.org/10.1007/s10661-011-2514-8

Körner C (2008) Winter crop growth at low temperature may hold the answer for alpine tree line formation. Plant Ecol Divers 1(1):3-11. https://doi.org/ 10.1080/17550870802273411

Kuzmicheva EA, Debella H, Khasanov B, Krylovich O, Babenko A, Savinetsky A, Severova E, Yirga S (2013) Holocene hyrax dung deposits in the afroalpine belt of the Bale Mountains (Ethiopia) and their palaeoclimatic implication. Environ Archaeol 18(1):72-81. https://doi.org/10.1179/1461410313Z. 00000000018

Kuzmicheva EA, Khasanov BF, Krylovich OA, Savinetsky AB (2014) Vegetation and climate reconstruction for the bale mountains (Ethiopia) in the Holocene according to the pollen analysis and radiocarbon dating of zoogenic deposits. Dokl Biol Sci 458(1):281-285. https://doi.org/10.1134/ S0012496614050019

Kuzyakov Y, Bogomolova I, Glaser B (2014) Biochar stability in soil: decomposition during eight years and transformation as assessed by compoundspecific ${ }^{14} \mathrm{C}$ analysis. Soil Biol Biochem 70:229-236. https://doi.org/10. 1016/j.soilbio.2013.12.021

Lamb HF, Bates CR, Coombes PV, Marshall MH, Umer M, Davies SJ, Dejen E (2007) Late Pleistocene desiccation of Lake Tana, source of the Blue Nile. Quat Sci Rev 26:287-299. https://doi.org/10.1016/j.quascirev.2006.11.020

Lamb HF, Bates CR, Bryant CL, Davies SJ, Huws DG, Marshall MH, Roberts HM, Toland H (2018) 150,000-year palaeoclimate record from northern Ethiopia supports early, multiple dispersals of modern humans from Africa. Nature. https://doi.org/10.1038/s41598-018-19601-w

Last MW, Smol PJ (2002) Tracking environmental change using lake sediments. Physical and geochemichal methods, 2nd edn. Kluwer Acadamic Publishers

Lemma B, Kebede Gurmessa S, Nemomissa S, Otte I, Glaser B, Zech M (2020) Spatial and temporal ${ }^{2} \mathrm{H}$ and ${ }^{18} \mathrm{O}$ isotope variation of contemporary precipitation in the Bale Mountains, Ethiopia. Isotopes Environ Health Stud 56(2):122-135. https://doi.org/10.1080/10256016.2020.1717487

Levin NE, Zipser EJ, Ceding TE (2009) Isotopic composition of waters from Ethiopia and Kenya: insights into moisture sources for eastern Africa. J Geophys Res Atmos 114(23):1-13. https://doi.org/10.1029/2009JD012166

Li F, Sun J, Zhao Y, Guo X, Zhao W, Zhang K (2010) Ecological significance of common pollen ratios: a review. Front Earth Sci China 4(3):253-258. https://doi.org/10.1007/s11707-010-0112-7

Litt T, Brauer A, Goslar T, Merkt J, Bałaga K, Müller H, Ralska-Jasiewiczowa M, Stebich M, Negendank JFW (2001) Correlation and synchronisation of Lateglacial continental sequences in northern central Europe based on annually laminated lacustrine sediments. Quat Sci Rev 20(11):1233-1249. https://doi.org/10.1016/S0277-3791(00)00149-9

Mark BG, Osmaston HA (2008) Quaternary glaciation in Africa: key chronologies and climatic implications. J Quat Sci 23(6-7):589-608. https://doi. org/10.1002/jqs.1222

Marshall JD, Brooks JR, Lajtha K (2007) Sources of variation in the stable isotopic composition of plants, 2nd edn. Blackwell Publishing

Marshall MH, Lamb HF, Huws D, Davies SJ, Bates R, Bloemendal J, Boyle J, Leng MJ, Umer M, Bryant C (2011) Late Pleistocene and Holocene drought events at Lake Tana, the source of the Blue Nile. Glob Planet Change 78(3-4):147-161. https://doi.org/10.1016/J.GLOPLACHA.2011.06.004

Mekonnen B, Zech W, Glaser B, Lemma B, Bromm T, Nemomissa S, Bekele T, Zech M (2019) Chemotaxonomic patterns of vegetation and soils along altitudinal transects of the Bale Mountains, Ethiopia, and implications for paleovegetation reconstructions - part l: stable isotopes and sugar biomarkers. E\&G Quat Sci J 68(2):177-188. https://doi.org/10.5194/ egqsj-68-189-2019

Messerli B (1980) Mountain glaciers in the Mediterranean area and in Africa. World Glacier Invent Work Publ 126:197-211

Messerli B, Winiger M (1992) Climate, environmental change, and resources of the African mountains from the Mediterranean to the equator. Mt Res Dev 12(4):315. https://doi.org/10.2307/3673683

Meyers PA (1994) Preservation of elemental and isotopic source identification of sedimentary organic matter. Chem Geol 114(3-4):289-302. https://doi. org/10.1016/0009-2541(94)90059-0
Miehe G, Miehe S (1994) Ericaceous forests and heathlands in the Bale Mountains of South Ethiopia: ecology and man's impact. Warnke

Mohtadi M, Prange M, Oppo DW, De Pol-Holz R, Merkel U, Zhang X, Steinke S, Lückge A (2014) North Atlantic forcing of tropical Indian Ocean climate. Nature 508(7498):76-80. https://doi.org/10.1038/nature13196

Monnin E, Indermühle A, Dällenbach A, Flückiger J, Stauffer B, Stocker TF, Raynaud D, Barnola JM (2001) Atmospheric $\mathrm{CO}_{2}$ concentrations over the last glacial termination. Science 291(5501):112-114. https://doi.org/10. 1126/science.291.5501.112

Moreno T, Querol X, Castillo S, Alastuey A, Cuevas E, Herrmann L, Mounkaila M, Elvira J, Gibbons W (2006) Geochemical variations in aeolian mineral particlesfrom the Sahara-Sahel Dust Corridor. Chemosphere 65:261-270

Nicholson SE (2000) The nature of rainfall variability over Africa on time scales of decades to millenia. Glob Planet Change 26(1-3):137-158. https://doi. org/10.1016/S0921-8181(00)00040-0

Osmaston HA, Mitchell WA, Osmaston JAN (2005) Quaternary glaciation of the Bale Mountains. J Quat Sci, Ethiopia. https://doi.org/10.1002/jqs.931

Ossendorf G, Groos AR, Bromm T, Tekelemariam MG, Glaser B, Lesur J, Schmidt J, Akçar N, Bekele T, Beldados A, Demissew S, Kahsay TH, Nash BP, Nauss T, Negash A, Nemomissa S, Veit H, Vogelsang R, Woldu Z, Zech W, Opgenoorth L, Miehe G (2019) Middle stone age foragers resided in high elevations of the glaciated Bale Mountains, Ethiopia. Science 365(6453):583-587. https://doi.org/10.1126/science.aaw8942

R Core Team. R: a language and environment for statistical computing. R Foundation for Statistical Computing; 2013. http://www.R-project.org.

Scheuvens D, Schütz L, Kandler K, Ebert M, Weinbruch S (2013) Bulk composition of northern African dust and its source sediments-a compilation. Earth Sci Rev 116:170-194. https://doi.org/10.1016/j.earscirev.2012.08.005

Schüler L, Hemp A (2016) Atlas of pollen and spores and their parent taxa of Mt Kilimanjaro and tropical East Africa. Quat Int 425:301-386. https://doi. org/10.1016/j.quaint.2016.07.038

Stager JC, Ryves DB, Chase BM, Pausata FSR (2011) Catastrophic drought in the Afro-Asian monsoon region during Heinrich event 1. Science 331(6022):1299-1302. https://doi.org/10.1126/science.1198322

Stockmarr J. Tablets with spores used in absolute pollen analysis. Pollen et Spores XIII: 615-621; 1971.

Talbot MR, Lærdal T (2000) The Late Pleistocene-Holocene palaeolimnology of Lake Victoria, East Africa, based upon elemental and isotopic analyses of sedimentary organic matter. J Paleolimnol 23(2):141-164. https://doi.org/ 10.1023/A:1008029400463

Talbot MR, Livingstone DA (1989) Hydrogen index and carbon isotopes of lacustrine organic matter as lake level indicators. Palaeogeogr Palaeoclimatol Palaeoecol 70:121-137

Thompson LG, Mosley-Thompson E, Davis ME, Henderson KA, Brecher HH, Zagorodnov VS, Mashiotta TA, Lin PN, Mikhalenko VN, Hardy DR, Beer J (2002) Kilimanjaro ice core records: evidence of holocene climate change in tropical Africa. Science 298(5593):589-593. https://doi.org/10.1126/ science. 1073198

Tiercelin JJ, Gibert E, Umer M, Bonnefille R, Disnar JR, Lézine AM, HureauMazaudier D, Travi Y, Keravis D, Lamb HF (2008) High-resolution sedimentary record of the last deglaciation from a high-altitude lake in Ethiopia. Quat Sci Rev 27(5-6):449-467. https://doi.org/10.1016/j.quascirev.2007. 11.002

Tierney JE, DeMenocal PB (2013) Abrupt shifts in Horn of Africa hydroclimate since the last glacial maximum. Science 342(6160):843-846. https://doi. org/10.1126/science.1240411

Tierney JE, Russell JM, Huang Y, Damsté JSS, Ellen C, Cohen AS (2008) Northern hemisphere controls on tropical southeast African climate during the past 60,000 years. Science 322:252-255. https://doi.org/10.1016/j.epsl. 2011.04.038,2011

Tierney JE, Lewis SC, Cook BI, Legrande AN, Schmidt GA (2011) Model, proxy and isotopic perspectives on the East African Humid Period. Earth Planet Sci Lett 307(1-2):103-112. https://doi.org/10.1016/j.epsI.2011.04.038

Umer M, Lamb HF, Bonnefille R, Lézine AM, Tiercelin JJ, Gibert E, Cazet JP, Watrin J (2007) Late Pleistocene and Holocene vegetation history of the Bale Mountains, Ethiopia. Quat Sci Rev 26(17-18):2229-2246. https://doi. org/10.1016/j.quascirev.2007.05.004

Van Campo E, Gasse F (1993) Pollen- and diatom-inferred climatic and hydrological changes in sumxi co basin (western tibet) since 13,000 yr B.P. Quat Res 39:300-313 
Van Raden UJ, Colombaroli D, Gilli A, Schwander J, Bernasconi SM, van Leeuwen J, Leuenberger M, Eicher U (2013) High-resolution late-glacial chronology for the Gerzensee lake record (Switzerland): $\delta^{18} \mathrm{O}$ correlation between a Gerzensee-stack and NGRIP. Palaeogeogr Palaeoclimatol Palaeoecol 391:13-24. https://doi.org/10.1016/j.palaeo.2012.05.017

Wang X, Li A (2007) Preservation of black carbon in the shelf sediments of the East China Sea. Chin Sci Bull 52(22):3155-3161. https://doi.org/10.1007/ s11434-007-0452-1

Wang YJ, Cheng H, Edwards RL, An ZS, Wu JY, Shen CC, Dorale JA (2001) A high-resolution absolute-dated late pleistocene monsoon record from Hulu Cave, China. Science 294(5550):2345-2348. https://doi.org/10.1126/ science. 1064618

Wiedemeier DB, Abiven S, Hockaday WC, Keiluweit M, Kleber M, Masiello CA, McBeath AV, Nico PS, Pyle LA, Schneider MPW, Smernik RJ, Wiesenberg GLB, Schmidt MWI (2015) Aromaticity and degree of aromatic condensation of char. Org Geochem 78:135-143. https://doi.org/10.1016/j.orgge ochem.2014.10.002

Yimer F, Ledin S, Abdelkadir A (2006) Soil property variations in relation to topographic aspect and vegetation community in the south-eastern highlands of Ethiopia. For Ecol Manag 232(1-3):90-99. https://doi.org/10. 1016/j.foreco.2006.05.055

Yineger H, Kelbessa E, Bekele T, Lulekal E (2008) Floristic composition and structure of the dry afromontane forest at Bale Mountains National Park, Ethiopia. J Sci 31 (2):103-120. https://doi.org/10.4314/sinet.v31i2.66551

Zech M, Glaser B (2008) Improved compound-specific $\delta^{13} \mathrm{C}$ analysis of $\mathrm{n}$-alkanes for application in palaeoenvironmental studies. RAPID Commun Mass Spectrom 22:135-142. https://doi.org/10.1002/rcm.3342

\section{Publisher's Note}

Springer Nature remains neutral with regard to jurisdictional claims in published maps and institutional affiliations.

\section{Submit your manuscript to a SpringerOpen ${ }^{\circ}$ journal and benefit from:}

- Convenient online submission

- Rigorous peer review

- Open access: articles freely available online

- High visibility within the field

- Retaining the copyright to your article

Submit your next manuscript at $\gg$ springeropen.com 